\title{
Characterisation of diarrhoeagenic Escherichia coli clones by ribotyping and ERIC-PCR
}

\author{
LIBERA M. DALLA-COSTA, KINUE IRINO*, J. RODRIGUES, IRMA N. G. RIVERA \\ and L. R. TRABULSI
}

Departamento de Microbiologia, Instituto de Ciências Biomédicas, Universidade de São Paulo and *Instituto Adolfo Lutz, São Paulo SP, Brazil

\begin{abstract}
The ability of ribotyping and enterobacterial repetitive intergenic concensus-polymerase chain reaction (ERIC-PCR) to discriminate diarrhoeagenic Escherichia coli clones of 122 strains belonging to 26 distinct serotypes was evaluated. The 26 serotypes corresponded to 24 ribotypes and 25 ERIC-types. Correlation between multilocus enzyme electrophoresis, ERIC-PCR and ribotyping was c. $90 \%$ for the dominant ribotypes. Related clones such as O55:H7 and 0157:H7 presented similar ribotypes and clustered together in a dendrogram, and the two divergent clonal groups of enteropathogenic $E$. coli (EPEC) and enterohaemorrhagic $E$. coli (EHEC) were included in distinct branches. The results suggest the possibility of applying these two simpler techniques as tools to identify clones of diarrhoeagenic $E$. coli.
\end{abstract}

\section{Introduction}

Escherichia coli shows a striking amount of intraspecific variation and includes strains able to colonise several habitats. A number of strains live as commensals in the animal and human intestine, but become opportunist pathogens when predisposing conditions favour their dissemination to extra-intestinal sites. Other strains are frank pathogens that can be associated with intestinal diseases. Criteria for characterising pathogenic $E$. coli include adherence pattern in cultured cells, presence of specific virulence genes and serotyping. Six categories of diarrhoeagenic E. coli (DEC) are recognised [1]: (i) enteropathogenic E. coli (EPEC), that show localised adherence and produce the attaching and effacing (AE) lesion in HEp-2 or HeLa cells; (ii) enterotoxigenic $E$. coli (ETEC), that produce the ST or LT enterotoxins, or both, and the CFA and CS adhesins; (iii) enterohaemorrhagic E. coli (EHEC), that produce Stx cytotoxins and cause AE lesions; (iv) enteroinvasive $E$. coli (EIEC), that cause shigellosislike dysentery and share virulence genes of Shigella; (v) enteroaggregative $E$. coli (EAggEC), distinguished by their ability to express an aggregative adherence pattern; and (vi) diffusely adhering E. coli (DAEC), also identified by their characteristic pattern of attachment to cultured cells.

The study of clonal structure has contributed to

Received 11 March 1997; revised version accepted 11 July 1997.

Corresponding author: Dr L. R. Trabulsi. assessing the pathogenic diversity of $E$. coli because it provides a reference framework for understanding the relationship between serotypes, virulence properties and strains [2]. Clonal analysis has revealed that most classical EPEC $O$ serogroups include strains displaying different virulence characteristics [3-7]. Most of this information has been derived from multilocus enzyme electrophoresis (MLEE) [8], frequently combined with other techniques such as those identifying outer-membrane protein and lipopolysaccharide profiles. Recently, analyses based on direct assessment of genomic DNA differences have been widely used for typing purposes. These include ribotyping [9], an analysis of fingerprint patterns of DNA digested with restriction endonucleases after a hybridisation reaction with the $16 \mathrm{~S}+23 \mathrm{~S}$ cDNA probe, and comparison of DNA products amplified with primers for repetitive sequences such as the enterobacterial repetitive intergenic consensus (ERIC) [10]. The purpose of this work was to evaluate the ability of these techniques to discriminate clones, as defined by MLEE, of diarrhoeagenic $E$. coli strains of different serotypes and distinct virulence properties.

\section{Materials and methods}

\section{Bacterial strains}

A collection of 122 E. coli strains, comprising 26 serotypes originally isolated in different geographic areas from diarrhoeic children, and previously characterised by MLEE and determination of specific virulence factors (Table 1) was studied. 
Table 1. Serotypes, virulence determinants and electrophoretic types of 122 diarrhoeagenic $E$. coli strains

\begin{tabular}{|c|c|c|c|c|}
\hline Serotype & $\begin{array}{c}\text { Number } \\
\text { of } \\
\text { strains }\end{array}$ & $\begin{array}{c}\text { Virulence } \\
\text { determinants* }\end{array}$ & $\begin{array}{l}\text { Electrophoretic } \\
\text { types }\end{array}$ & Reference \\
\hline O55:H6 & 9 & $e a e A, b f p A, \mathrm{EAF}$ & ET 1 & [6] \\
\hline $\mathrm{O} 55: \mathrm{H} 7$ & 4 & eaeA & ET 5 & [6] \\
\hline O55:H7 & 1 & eaeA & ET 7 & [6] \\
\hline O111 ac: $\mathrm{H}^{-}$ & 1 & None & ET 2 & [4] \\
\hline $\mathrm{O} 111 \mathrm{ab}: \mathrm{H}^{-}$ & 1 & None & ET 7 & [4] \\
\hline O111ac:H- & 1 & $e a e A$, stxl & ET 8 & [4] \\
\hline O111ac:H $H^{-}$ & 2 & eaeA, stxl, EHEC plasmid & ET 8 & [4] \\
\hline O111ac: $\mathrm{H}^{-}$ & 3 & eaeA & ET 8 & [4] \\
\hline O11lab:H- & 3 & eaeA & ET 9 & [4] \\
\hline $\mathrm{O} 111 \mathrm{ab}: \mathrm{H}^{-}$ & 4 & $e a e A$, EAF & ET 12 & [4] \\
\hline $\mathrm{O} 111 \mathrm{ab}: \mathrm{H}^{-}$ & 5 & $e a e A$, EAF, bfp $A$ & ET 12 & [4] \\
\hline O111ab:H2 & 5 & $e a e A$, EAF & ET 12 & [4] \\
\hline $\mathrm{O} 111 \mathrm{ab}: \mathrm{H} 2$ & 1 & $e a e A, \mathrm{EAF}, b f p A$ & ET 12 & [4] \\
\hline O111ac:H4 & 1 & None & ET 1 & [4] \\
\hline O111ac:H8 & 1 & eaeA, stxl, EHEC plasmid & ET 8 & [4] \\
\hline O111ab:H9 & 1 & eaeA & ET 16 & [4] \\
\hline O111ab:H9 & 2 & eaeA & ET 9 & [4] \\
\hline O111ac:H9 & 3 & eaeA & ET 9 & [4] \\
\hline O11lab:H10 & 3 & AA & ET 1 & [4] \\
\hline O11lab:H10 & 1 & None & ET 5 & [4] \\
\hline O11lab:H12 & 11 & None & ET 1 & [4] \\
\hline O111ab:H25 & 1 & $e a e A$ & ET 3 & [4] \\
\hline O111ab:H25 & 1 & eaeA & ET 4 & [4] \\
\hline $\mathrm{O} 119: \mathrm{H}^{-}$ & 1 & $e a e A$ & ND & [5] \\
\hline $\mathrm{O} 119: \mathrm{H}^{-}$ & 1 & $e a e A, \mathrm{EAF}, b f p A$ & ET 1 & [5] \\
\hline $\mathrm{O} 119: \mathrm{H}^{-}$ & 2 & eaeA & ET 1 & [5] \\
\hline $\mathrm{O} 119: \mathrm{H}^{-}$ & 1 & $e a e A, b f p A$ & ET 1 & [5] \\
\hline $\mathrm{O} 119: \mathrm{H} 2$ & 4 & $e a e A, b f p A$ & ET 7 & [5] \\
\hline $\mathrm{O} 119: \mathrm{H} 2$ & 1 & $e a e A, b f p A$ & ET 8 & [5] \\
\hline $\mathrm{O} 119: \mathrm{H} 2$ & 1 & $e a e A, b f p A$ & ET 9 & [5] \\
\hline O119:H6 & 6 & $e a e A$, EAF, $b f p A$ & ND & [5] \\
\hline O119:H6 & 2 & eaeA & ND & {$[5]$} \\
\hline O119:H6 & 5 & $e a e A$, EAF, $b f p A$ & ET 1 & [5] \\
\hline O119:H6 & 2 & eaeA & ET 1 & {$[5]$} \\
\hline O119:H6 & 1 & $e a e A, \mathrm{EAF}, b f p A$ & ET 5 & [5] \\
\hline O119:H6 & 2 & $e a e A, \mathrm{EAF}, b f p A$ & ET 6 & {$[5]$} \\
\hline O119:H6 & 1 & $e a e A$, EAF & ET 5 & [5] \\
\hline O119:H7 & 1 & eaeA, bfpA & ET 8 & [5] \\
\hline O119:H18 & 1 & None & ET 11 & [5] \\
\hline O128ab:H2 & 2 & None & ND & - \\
\hline O128ab:H2 & 1 & $e a e A, b f p A$ & ND & - \\
\hline O128ab:H8 & 1 & None & ND & - \\
\hline O128ac:H8 & 1 & None & ND & - \\
\hline O128ab:H12 & 2 & None & ND & - \\
\hline O128ac:H27 & 2 & None & ND & - \\
\hline O128ab:H35 & 3 & None & ND & - \\
\hline $0157: \mathrm{H}^{-}$ & 1 & LT-I & DEC 7 & {$[17]$} \\
\hline $\mathrm{O} 157: \mathrm{H} 7$ & 3 & eaeA, stx1, stx2, EHEC plasmid & DEC 3 & {$[17]$} \\
\hline O157:H7 & 1 & $e a e A$, stx 2, EHEC plasmid & DEC 3 & {$[17]$} \\
\hline O157:H7 & 4 & $e a e A$, stx 2 , EHEC plasmid & DEC 4 & {$[17]$} \\
\hline O157:H7 & 1 & $e a e A$, stx 1 & DEC 4 & {$[17]$} \\
\hline $\mathrm{O} 157: \mathrm{H} 43$ & 1 & None & DEC 7 & {$[17]$} \\
\hline $\mathrm{O} 157: \mathrm{H} 43$ & 2 & LT-I & DEC 7 & {$[17]$} \\
\hline
\end{tabular}

ND, ET not determined.

*Virulence determinants: eaeA, E. coli attaching and effacing gene encoding intimin; EAF, EPEC adherence factor; AA, aggregative adherence factor; stx 1 and $s t x 2$, genes coding for Shiga cytotoxins 1 and 2 , respectively; LTI, heat-labile enterotoxin gene; $b f p A$, gene coding for bundlin, the structural subunit of the bundle forming pili (BFP).

\section{Extraction of genomic DNA}

DNA extraction was performed according to Brenner et al. [11].

\section{$D N A$ cleavage and reaction with the $16 S+23 S$ cDNA probe}

DNA $(2 \mu \mathrm{g})$ was digested with $B g l \mathrm{I}$ and HindIII (New England Biolabs Inc., Beverly, MA, USA), electro- phoresed in agarose $0.8 \%$ gel, and transferred to nylon membranes (Schleicher and Schuell Inc., Keene, USA) by Southern blotting [12]. The procedures for labelling the $16 \mathrm{~S}+23 \mathrm{~S}$ rRNA, and the detection and hybridisation conditions were performed as described by Popovic et al. [13]. The $16 \mathrm{~S}+23 \mathrm{~S}$ cDNA probe was prepared by reverse transcription of the $16 \mathrm{~S}+23 \mathrm{~S}$ rRNA with a DIG DNA labelling and detection kit (Boehringer Mannheim, Germany). 


\section{ERIC-PCR conditions and primers}

PCR was performed with the following primer sequences [10]: ERIC1R, 5'ATGTAAGCTCCTGGGGATTCAC3' and ERIC2, 5'AAGTAAGTGACTGGGGTGAGCG3'. Each 20- $\mu 1$ PCR reaction mixture contained: $100 \mathrm{pmol}$ of forward and reverse primers; $1 \mu \mathrm{l}$ of template DNA (c. $0.10 \mu \mathrm{g}$ ); $0.8 \mu \mathrm{l}$ each of $1.5 \mathrm{mM}$ dATP, dCTP, dGTP and dTTP; $2 \mu \mathrm{l}$ of Mg-free $10 \times$ amplification buffer $(500 \mathrm{mM} \mathrm{KCl}, 100 \mathrm{mM}$ Tri$\mathrm{HCl}, \mathrm{pH} 9.0 ; 1 \%$ triton $\mathrm{X}-100) ; 1.5 \mu \mathrm{l}$ of $25 \mathrm{mM} \mathrm{MgCl}$; $2.5 \mathrm{U}$ of Taq DNA polymerase (Perking-Elmer/Cetus) and dimethyl sulphoxide (Sigma) 10\%. The mixture was overlaid with one drop of sterile mineral oil and placed in an automated thermocycler (DNA MiniCycler, MJ Research, Watertown, MA, USA).

The DNA in the reaction mixture was denatured at $95^{\circ} \mathrm{C}$ for $5 \mathrm{~min}$. PCR amplification was done as follows: denaturation at $92^{\circ} \mathrm{C}$ for $45 \mathrm{~s}$, annealing at $52^{\circ} \mathrm{C}$ for $1 \mathrm{~min}$, and extension at $70^{\circ} \mathrm{C}$ for $10 \mathrm{~min}$, with a final extension at $70^{\circ} \mathrm{C}$ for $20 \mathrm{~min}$ at the end of 35 cycles. The samples were then held at $4^{\circ} \mathrm{C}$. The PCR products were separated by agarose gel electrophoresis in TAE buffer $(0.04 \mathrm{M}$ Tris-acetate, $0.001 \mathrm{M}$ EDTA).

\section{Fingerprint analysis}

The sizes of DNA fragments that hybridised with the $16 \mathrm{~S}+23 \mathrm{~S}$ cDNA probe and those of the bands generated by ERIC-PCR were calculated with the DNASTAR software (DNASTAR Computer Systems for Molecular Biology and Genetics, London) with Haemophilus aegyptius 3031 DNA digested with EcoR1 and a 1-kb DNA ladder (BRL-Gibco) as reference markers for ribotyping and ERIC-PCR, respectively. Groups of strains showing identical fingerprints (FPs) were designed as ribotypes (RTs) or ERIC-types.

Genetic relationships and divergence between RTs were calculated from a genetic distance matrix, defined on the basis of similarity between the distinct FPs and represented in a dendrogram constructed with the Neighbour-Joining algorithm [14].

\section{Results \\ Ribotypes and ERIC-types}

RFLP analysis of DEC strains revealed 24 distinct ribotypes (RTs), defined by fingerprints (FPs) with band sizes ranging from c. $1.7-15.8 \mathrm{~kb}$ (Fig. 1). Twelve of the 24 RTs were represented by multiple strains and $74 \%$ of these were included in six RTs (D, $\mathrm{H}, \mathrm{K}, \mathrm{O}, \mathrm{U}$ and $\mathrm{V}$ ). In the ERIC-PCR analysis, the strains presented 25 different FPs (ERIC-types) with band sizes of $0.8-4.5 \mathrm{~kb}$ (data not shown). Multiple strains were observed in 12 of the 25 ERIC-types.

Because there was a good association between RT and ERIC-types (as shown below), the data on ERIC-PCR are presented only where divergence occurred between the two techniques.

\section{Serotypes, virulence markers and genetic relationship among $R T s$}

A dendrogram based on a matrix of similarity of the different FPs was constructed that illustrates the degree of divergence among the RTs, clustered in three groups (I, II, III) (Fig. 2).

All the RTs of group I, except RT E, had the O111 antigen and included strains possessing some virulence markers of DEC. The dominant RT in this group (D) included strains having the aggregative adherence phenotype or genotype, or both. In addition to $\mathrm{H} 12$ (the most common $\mathrm{H}$ type in this group), one $\mathrm{H} 4$ and three H10 strains were also included in this RT. Furthermore, the single $\mathrm{H} 4$ strain had the O111ac antigen, in contrast to the remaining ones which were typed as O111ab (Fig. 2).

RTs of group II were marked by serotypes of four distinct serogroups: O55, O119, O128 and O157. RTs F-I clustered in a subgroup of O55:H7, O157:H7, O157:H43 and $0157: \mathrm{H}^{-}$strains. RT $\mathrm{H}$ marked the O157:H7, Stx-producing strains, referred to as EHEC 1 by Whittam and McGraw [15]. Group II also included RTs with the $\mathrm{H} 6$ antigen and harbouring a complete EAF plasmid (with the $b f p A$ gene and the EAF region, see Table 1). Strains of these RTs are considered as typical EPEC [16], and as belonging to the EPEC 1 clonal group [15].

Group III was a second divergent group of 0111 , but also included strains of serogroups O119 and O128. The dominant RT (U) has all these three serogroups and shows features of EPEC 2 [15]: namely, the presence of the $\mathrm{H} 2$ antigen and of some $\mathrm{O} 119$ and O128 strains with an incomplete EAF plasmid (EAF-, $b f p A+)$ [5] (Table 1). The O111/Stx-producing strains, which belong to the EHEC 2 clonal group [15], were marked by RT V. Strains of RTs Q, R and $\mathrm{T}$ had no known virulence genes and that of RT $\mathrm{S}$ represented the O119:H7 strain with an incomplete EAF plasmid. Strains of remaining RTs (W and X) had only the eaeA gene (Fig. 2).

\section{ERIC-types and ETs within DEC ribotypes}

Twenty-one of the 24 RTs included strains of a single motile serotype and RTs of non-motile serotypes. Fig. 3 illustrates the relationship between ERIC-types, ETs and RTs for 10 representative RTs with more than three strains. There was $100 \%$ agreement in the discriminatory power of ERIC-PCR, ribotyping, serotyping and MLEE for five of the 10 RTs. For MLEE and ribotyping the absolute association was observed in eight ribotypes and for ERIC-PCR and ribotyping, the association was seen in seven ribotypes (Fig. 3). For 

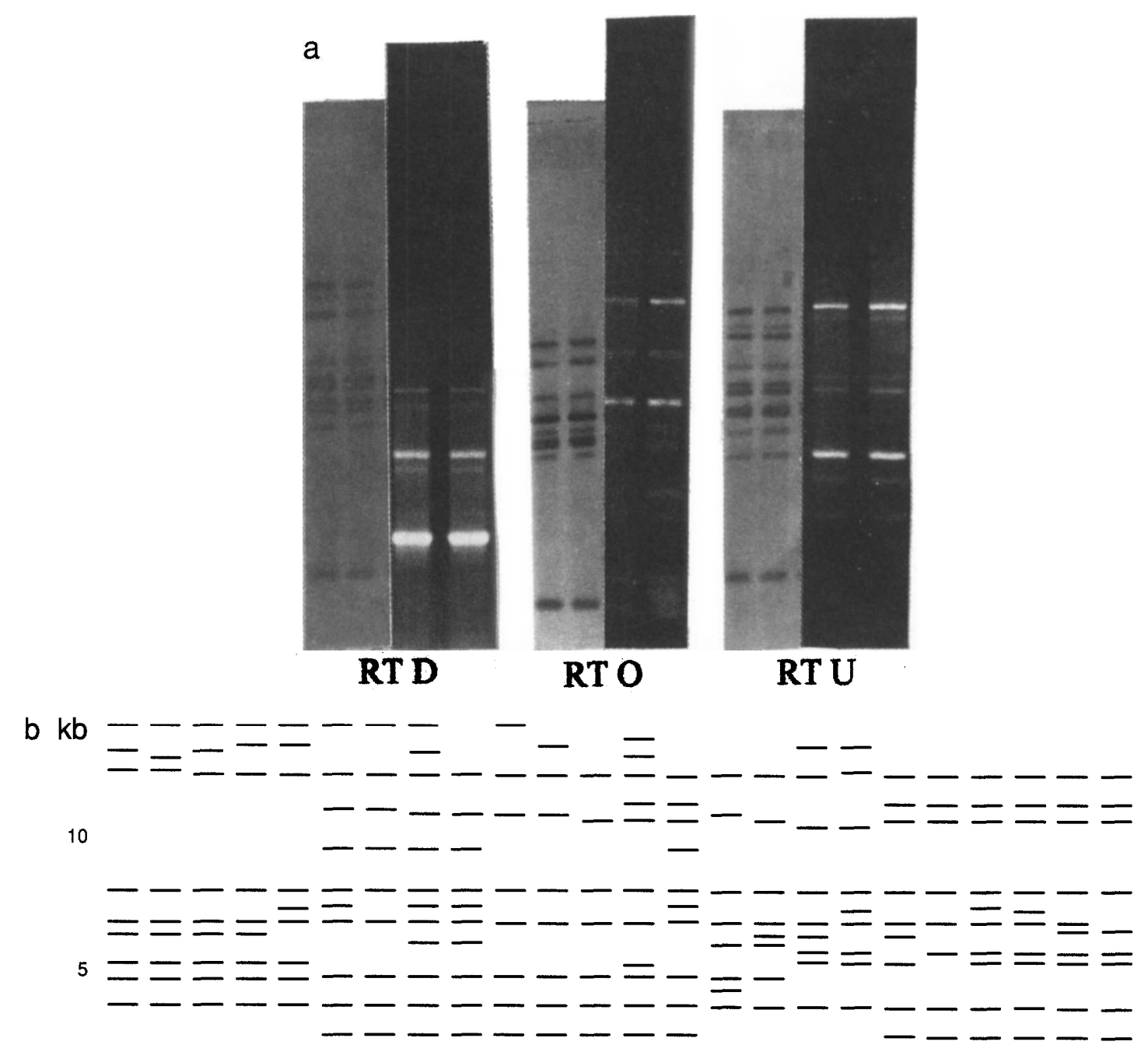

2

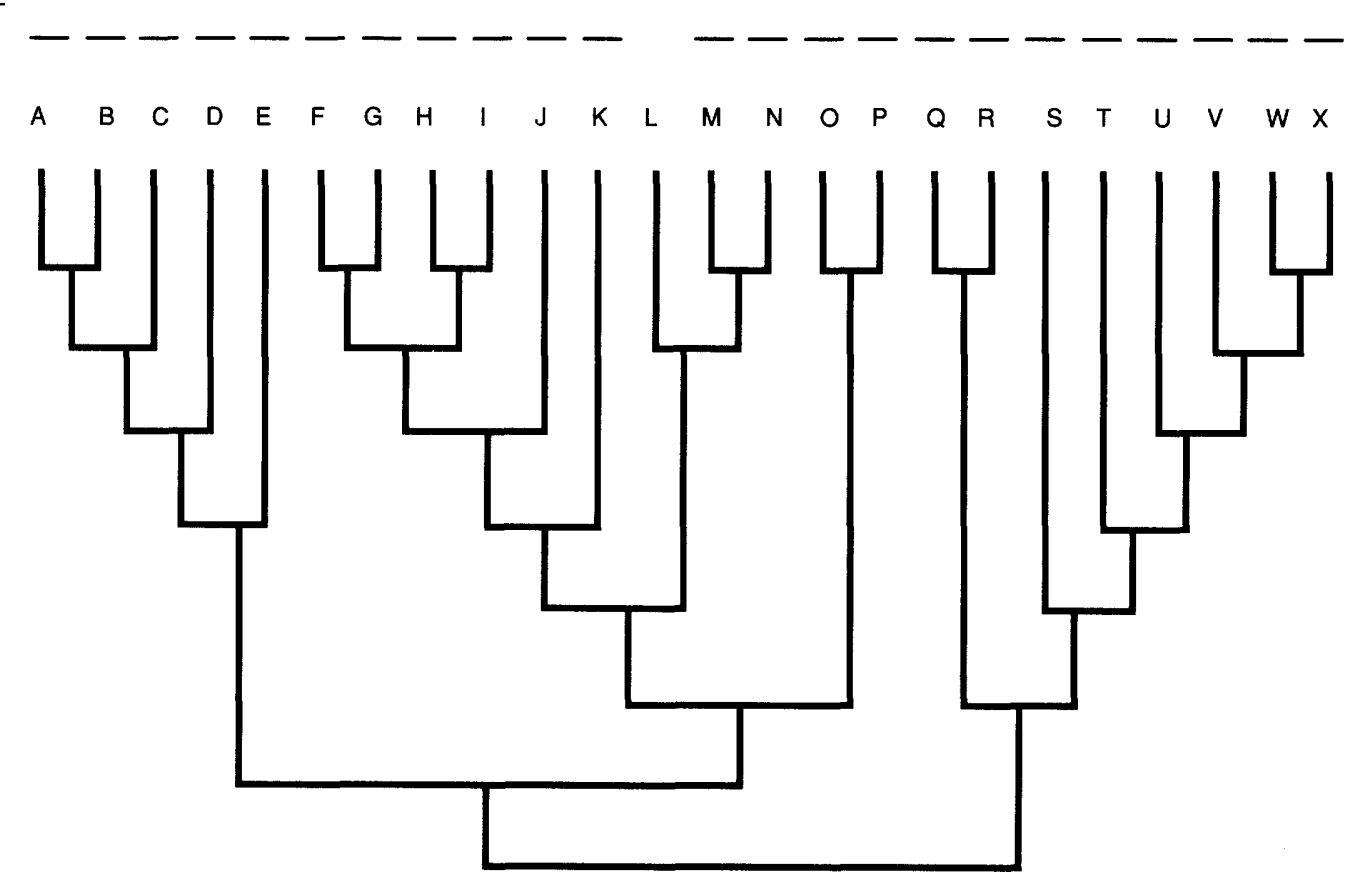

Fig. 1. Fingerprints that define DEC clones. (a) RTs (left) and ERIC-types (right) of dominant RTs in each of the three divergent clonal groups. (b) Schematic representation of fingerprints of each RT obtained by DNA digestion with the enzyme $B g l \mathrm{I}$. 


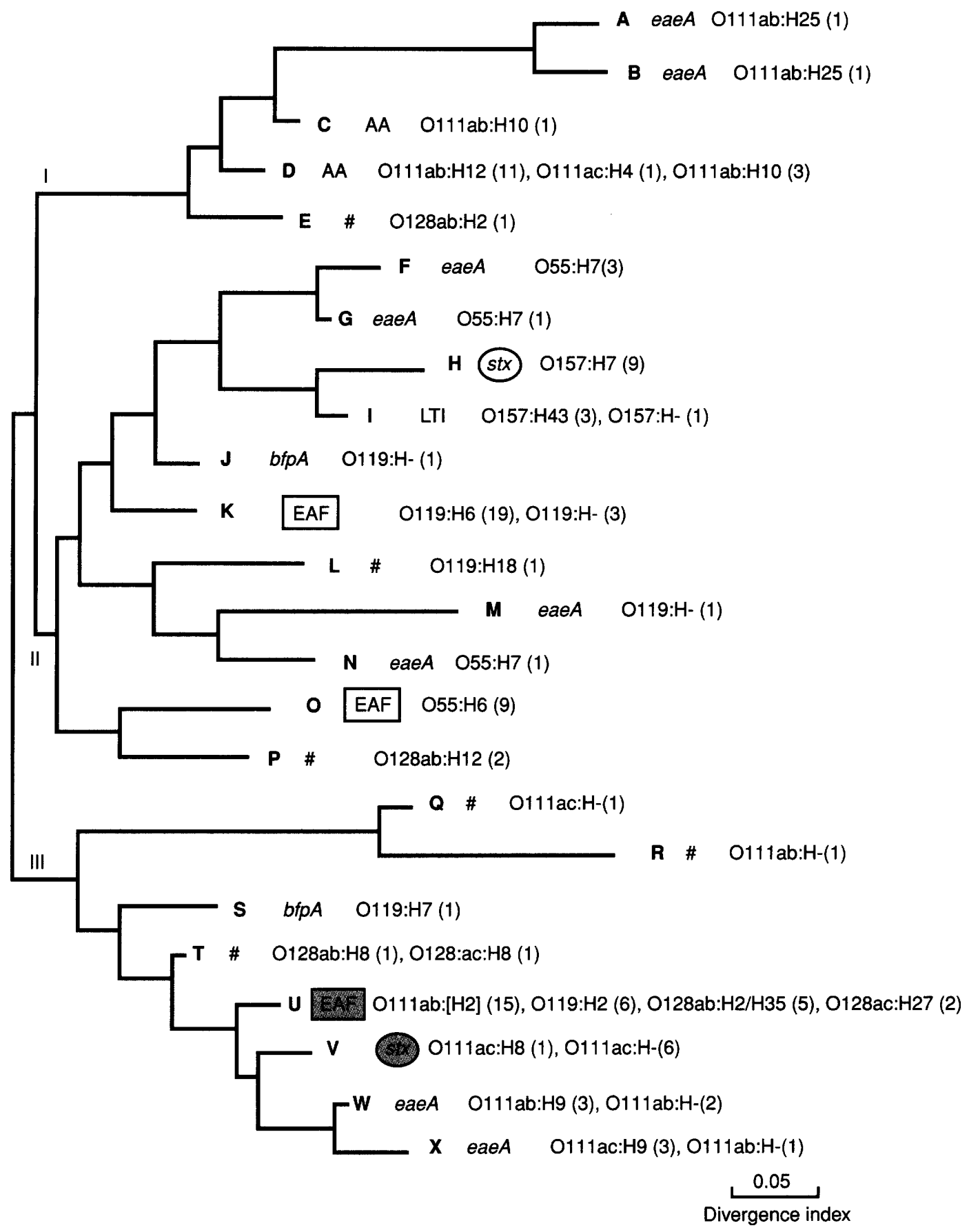

Fig. 2. Genetic relationship between RTs of DEC and common virulence traits. Serotypes are indicated on the right. Box and ellipses mark the two main clonal groups of EPEC and EHEC, respectively. Empty symbols, EPEC 1 and EHEC 1; shaded, EPEC 2 and EHEC 2. \#, indicates absence of known virulence markers of diarrhoeagenic E. coli; ( ), number of strains; [ ], includes nonmotile strains.

RT D, which included more than one serotype, the association between ET, ERIC type and RT was $>90 \%$. RT $\mathrm{H}$ with nine $\mathrm{O} 157: \mathrm{H} 7$ strains, was resolved in a single ERIC type, but corresponded to two distinct ETs each of four and five strains.

\section{Discussion}

One hundred and twenty-two DEC strains were characterised by ribotyping and ERIC-PCR. With the exception of strains of serogroup $\mathrm{O} 128$ and some of
O119, all the strains had been analysed previously by MLEE and investigated for characteristic virulence properties. All strains, including 23 ETs in 26 serotypes and displaying virulence markers of EPEC, EHEC, EAggEC and ETEC, were grouped in 24 distinct RTs and 25 ERIC-types. Generally, strains of a single ET were included in the same RT and ERIC-type and most RTs had motile and non-motile strains of the same O serotype. However, RT D contained O111 strains of three different $\mathrm{H}$ types (H4, H10 and H12) and RT U contained strains of serogroups O111, O119 and O128. The O111:H4, O111:H10 and O111:H12 


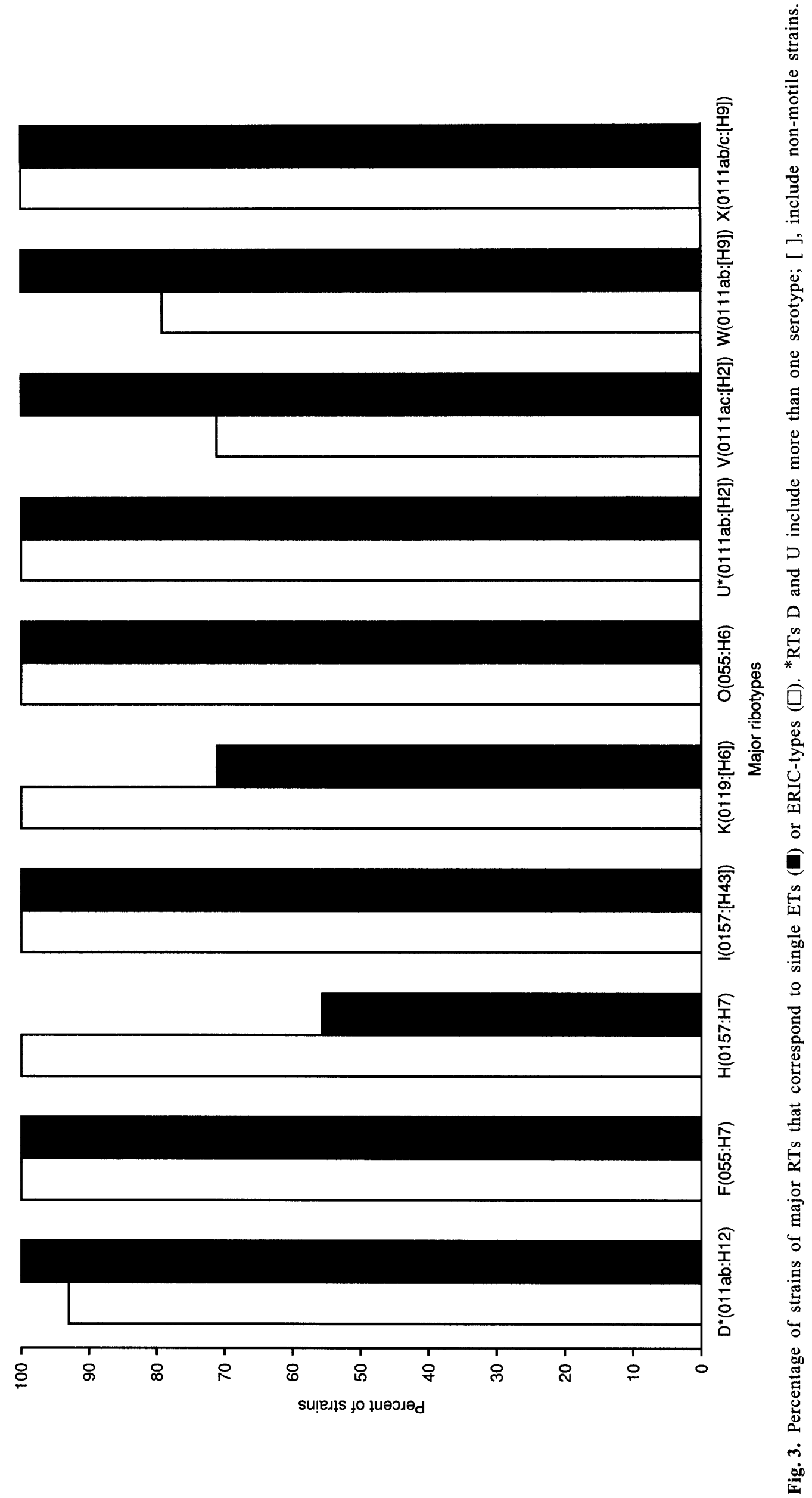


strains of RT D belong to a single ET (ET1 [4]). The O119:H2 strains of RT U belonged to the related ETs 7,8 and 9 (cluster B, Fig. 2 of reference [5]). The MLEE genotype of ET 7 [5] matches that of DEC 11 (O128:H2) [17] and differs from the O111: H2/ET 12 [4] for only the PGD enzyme. The O128:H27 and O128:H35 strains, in turn, cluster with O128:H2 [17]. These ETs mark a clone complex representing a subgroup of EPEC, referred to as EPEC 2, and characterised by a high frequency of $\mathrm{H} 2$ strains [15]. In addition, some O119:H2 [5] and O128:H2 strains of this group harbour an incomplete EAF plasmid (data not shown). Interestingly, these groups of strains, although belonging to different ETs and $\mathrm{O}: \mathrm{H}$ types, were included in a single RT.

RTs $\mathrm{K}$ and $\mathrm{O}$ of serogroups $\mathrm{O} 119$ and O55, respectively, represent EPEC 1, marked by EPEC serogroups having the $\mathrm{H} 6$ and $\mathrm{H} 34$ flagellar antigen [15], whose divergence from EPEC 2 had as a consequence the accumulation of differences in the intimin gene. The present study demonstrated that divergence also occurred in the $16 \mathrm{~S}+23 \mathrm{~S}$ rRNA conserved sequence and in the distribution of ERIC. The same was true for the two groups of EHEC (EHEC 1 and EHEC 2), which were included in separate branches of the dendrograms. EHEC 1 comprised the stx+ strains of the serotype $0157: \mathrm{H} 7$, and EHEC 2 the stx+ strains of serogroups $\mathrm{O} 26$ and 0111 [15]. The close relationship between the O157:H7 and the O55:H7 clones (RTs F, G and H) was also evident from the ribotyping and ERIC-PCR data; this association was supported by a statistical significance level (bootstrapping value) of $68 \%$ (data not shown).

The analysis of clonal structure of bacteria has been performed by MLEE, a technique that detects polymorphism in a set of conserved metabolic enzymes, which is assumed to reflect genetic variation of the whole genome [8]. Recently, several other molecular typing methods have been applied with the same purpose. Since the initial proposal of Grimont and Grimont [9], ribotyping has emerged as an important taxonomic tool for bacterial pathogens. Yet the discriminatory ability varies from species to species. For strains of Yersinia enterocolitica, it has been viewed as an alternative for bioserotyping [18], but it proved not to be a reference method to discriminate Salmonella [19]. In 1991, Tarkka et al. [20] observed an association between $\mathrm{O}: \mathrm{H}: \mathrm{K}$ serotypes and ribotyping for clinical isolates of $E$. coli. In the present study, the lower association of ribotyping with MLEE was observed for the 0157:H7 strains, marked by RT H. Four of the nine strains in this RT belonged to a distinct ET. This result supports that of Martin et al. [21] who showed that ribotyping was not the best technique to discriminate strains of $0157: \mathrm{H} 7$. However, the MLEE genotype of DEC3 and DEC4 differs in a single enzyme [17].
Analyses based on the distribution of ERIC sequences were done for environmental strains of several bacteria [22-23]. In their study of the genetic structure of two biovars of soil Rhizobium leguminosarum, Strain et al. [23] observed a very close association between MLEE and ERIC-PCR data. Although the latter was more discriminatory, strains of a single ET were included in closely related ERIC-types. In 1995, Rivera et al. [24] found that toxigenic strains of Vibrio cholerae $\mathrm{O} 1$ and O139 from different locations showed identical FPs for the ERIC sequences and were only distantly related to the non-toxigenic strains. For Shigella sonnei, the ability of ERIC-PCR to discriminate clones was equivalent to that of pulsed-field gel electrophoresis [25], which is increasingly becoming a reference molecular technique for typing bacteria [18, 19, 21]. More recently, ERIC-PCR was also evaluated in a comparative test with several PCR-based techniques to discriminate strains of the Acinetobacter calcoaceticus- $A$. baumannii complex [26]. However, for these bacteria REP-PCR presented a more discriminatory power than ERIC-PCR. Thus, ERICPCR seems more fitted for the identification of enteric bacteria.

Ribotyping and ERIC-PCR were used to identify 23 DEC clones, previously defined by MLEE, which has been the main reference technique for the study of genetic variation in natural populations of bacteria. Both ribotyping and ERIC-PCR could discriminate the clones well, and there was a good correlation between them. The results of the present study suggest the suitability of these easier and faster techniques for the study of genetic variation within DEC strains.

This work was supported by grants 62.02366/92-2 (PADCT/CNPq) and 92/4890-2 (FAPESP) awarded to L.R.T.

\section{References}

1. Kaper JB. Molecular pathogenesis of enteropathogenic Escherichia coli. In: Miller VL, Kaper JB, Portnoy DA, Isberg RJR. (eds) Molecular genetics of bacterial pathogenesis. Washington, DC, American Society for Microbiology. 1994: 173-195.

2. Whittam TS. Genetic population structure and pathogenicity in enteric bacteria. In: Baumberg S, Young JPW, Wellington EMH, Saunders JR (eds) Population genetics of bacteria. Cambridge, Cambridge University Press. 1995: 217-245.

3. Beutin L, Ørskov I, Ørskov F et al. Clonal diversity and virulence factors in strains of Escherichia coli of the classic enteropathogenic serogroup 0114. J Infect Dis 1990; 162: 1329-1334.

4. Campos LC, Whittam TS, Gomes TAT, Andrade JRC, Trabulsi LR. Escherichia coli serogroup O111 includes several clones of diarrheagenic strains with different virulence properties. Infect Immun 1994; 62: 3282-3288.

5. Goncalves AG, Campos LC, Gomes TAT et al. Virulence properties and clonal structures of strains of Escherichia coli O119 serotypes. Infect Immun 1997; 65: 2034-2040.

6. Rodrigues J, Scaletsky ICA, Campos LC, Gomes TAT, Whittam TS, Trabulsi LR. Clonal structure and virulence factors in strains of Escherichia coli of the classic serogroup O55. Infect Immun 1996; 64: 2680-2686.

7. Yam WC, Robins-Browne RM, Lung ML. Genetic relationships and virulence factors among classical enteropathogenic 
Escherichia coli serogroup 0126 strains. $J$ Med Microbiol 1994; 40: 229-235.

8. Selander RK, Caugant DA, Ochman H, Musser JM, Gilmour MN, Whittam TS. Methods of multilocus enzyme electrophoresis for bacterial population genetics and systematics. Appl Environ Microbiol 1986; 51: 873-884.

9. Grimont F, Grimont PAD. Ribosomal ribonucleic acid gene restriction patterns as potential taxonomic tools. Ann Inst Pasteur Microbiol 1986; 137B: 165-175.

10. Versalovic J, Koeuth T, Lupski JR. Distribution of repetitive DNA sequences in eubacteria and aplication to fingerprinting of bacterial genomes. Nucleic Acids Res 1991; 19: 6823-6831.

11. Brenner DJ, McWhorter AC, Knutson. JKL, Steigerwalt AG. Escherichia vulneris: a new species of Enterobacteriaceae associated with human wounds. J Clin Microbiol 1982; 15: 1133-1140.

12. Sambrook J, Fritsch EF, Maniatis T. Analysis of genomic DNA by Southern hybridization. In: Sambrook J, Fritsch EF, Maniatis T (eds) Molecular cloning: a laboratory manual, vol 2, 2nd edn. Cold Spring Harbor, NY, Cold Spring Harbor Laboratory Press. 1989: 9.31.

13. Popovic T, Bopp CA, Olsvik O et al. Ribotyping in molecular epidemiology. In: Persing DH, Tenover FC, Smith TF, White TJ (eds) Diagnostic molecular microbiology. Washington, DC, American Society for Microbiology. 1993: 573-583.

14. Kumar S, Tamura K, Masatoshi N. MEGA: Molecular Evolutionary Genetic Analysis, version 1.0. The Pennsylvania State University, University Park, PA, USA. 16802.

15. Whittam TS, McGraw EA. Clonal analysis of EPEC serogroups. Rev Microbiol Sao Paulo 1996; 27 Suppl 1: 7-16.

16. Kaper JB. Defining EPEC. Rev Microbiol Sao Paulo 1996; 27 Suppl 1: 130-133.

17. Whittam TS, Wolfe ML, Wachsmuth IK, Ørskov F, Ørskov I, Wilson RA. Clonal relationships among Escherichia coli strains that cause hemorrhagic colitis and infantile diarrhea. Infect Immun 1993; 61: 1619-1629.
18. Iteman I, Guiyoule A, Carniel E. Comparison of three molecular methods for typing and subtyping pathogenic Yersinia enterocolitica strains. J Med Microbiol 1996; 45: 48-56.

19. Liebisch B, Schwarz S. Molecular typing of Salmonella enterica subsp. enterica serovar Enteritidis isolates. $J$ Med Microbiol 1996; 44: 52-59.

20. Tarkka E, Ahman H, Siitonen A. Ribotyping as an epidemiologic tool for Escherichia coli. Epidemiol Infect 1994; 112: $263-274$.

21. Martin IE, Tyler SD, Tyler KD, Khakhria R, Johnson WM. Evaluation of ribotyping as epidemiologic tool for typing Escherichia coli serogroup 0157 isolates. J Clin Microbiol 1996; 34: 720-723.

22. de Bruijn FJ. Use of repetitive (repetitive extragenic palindromic and enterobacterial repetitive intergenic consensus) sequences and the polymerase chain reaction to fingerprint the genomes of Rhizobium meliloti isolates and other soil bacteria. Appl Environ Microbiol 1992; 58: 2180-2187.

23. Strain SR, Leung K, Whittam TS, de Bruijn FJ, Bottomley PJ Genetic structure of Rhizobium leguminosarum biovar trifolii and viciae populations found in two Oregon soils under different plant communities. Appl Environ Microbiol 1994; 60: 2772-2778.

24. Rivera IG, Chowdhury MAR, Huq A, Jacobs D, Martins MT, Colwell RR. Enterobacterial repetitive intergenic consensus sequences and the PCR to generate fingerprints of genomic DNAs from Vibrio cholerae $\mathrm{O} 1, \mathrm{O} 139$, and non-O1 strains. Appl Environ Microbiol 1995; 61: 2898-2904.

25. Liu PY-F, Lau Y-J, Hu B-S et al. Analysis of clonal relationships among isolates of Shigella sonnei by different molecular typing methods. J Clin Microbiol 1995; 33: 1779-1783.

26. Vila J, Marcos MA Jimenez de Anta MT. A comparative of different PCR-based DNA fingerprinting techniques for typing of the Acinetobacter calcoaceticus-A. baumannii complex. J Med Microbiol 1996; 44: 482-489. 